\title{
Aboveground biomass of a Eucalyptus hybrid subjected to two water regimes
}

\author{
Gian Carlos Poleto ${ }^{1}$, Kristiana Fiorentin dos Santos ${ }^{2} \oplus$, Aline Aparecida Ludvichak ${ }^{1} \oplus$,

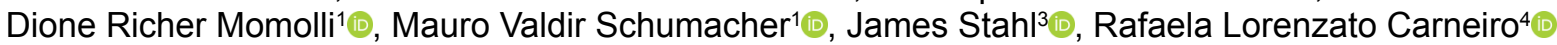

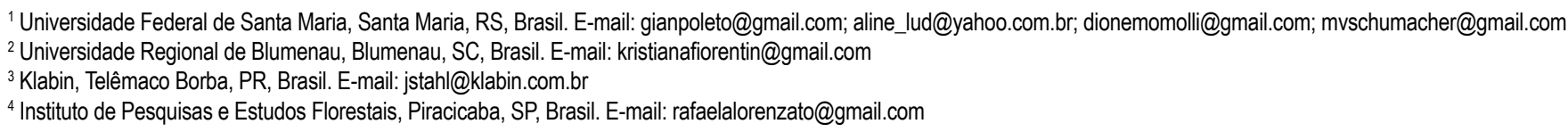

ABSTRACT: The objective of this work was to estimate the aboveground biomass production of 76-month-old, Eucalyptus urophylla $\times$ Eucalyptus sp. hybrids, subjected partial exclusion of throughfall. The experiment used two water regimes: one treatment with throughfall (WET), receiving 100\% of the throughfall, and the other treatment with the partial exclusion of throughfall (PET), receiving only $70 \%$. The selected trees were sectioned and fractionated into the following components: leaves, branches, stembark, and stemwood. The WET treatment had higher total biomass $\left(221.00 \mathrm{Mg} \mathrm{ha}^{-1}\right)$ than the PET treatment $\left(206.26 \mathrm{Mg} \mathrm{ha}^{-1}\right)$ and the distribution of biomass for both treatments was as follows: stemwood > branches > stembark > leaves. The stem (wood + bark) accounted for $91.5 \%$ of the total biomass in the WET treatment and $91.2 \%$ in the PET treatment. The canopy (leaves + branches) accounted for $8.5 \%$ and $9.0 \%$ in the WET and PET treatments, respectively. These results indicate that this Eucalyptus hybrid maintained satisfactory biomass production, despite the lower availability of water.

Key words: drought tolerance; exclusion of throughfall; tree growth; tree productivity; water deficit

\section{Biomassa acima do solo de um híbrido de Eucalyptus submetido a dois regimes hídricos}

RESUMO: O objetivo deste trabalho foi estimar a produção de biomassa acima do solo de um híbrido de Eucalyptus urophylla $\times$ Eucalyptus sp. com 76 meses de idade submetido a exclusão parcial da precipitação interna. $O$ experimento foi instalado em dois regimes hídricos: um recebendo $100 \%$ da precipitação interna, tratamento sem exclusão da precipitação interna (SEPi) e o outro recebendo apenas 70\%, tratamento com exclusão parcial da precipitação interna (CEPi). Após a seleção das árvores, elas foram seccionadas e fracionadas nos componentes: folhas, galhos, casca do tronco e madeira do tronco. 0 tratamento SEPi apresentou valor superior de biomassa total $\left(221,00 \mathrm{Mg} \mathrm{ha}^{-1}\right)$ em comparação ao tratamento CEPi $\left(208,26 \mathrm{Mg} \mathrm{ha}^{-1}\right)$. A biomassa, para ambos os tratamentos, foi distribuída na seguinte ordem: madeira do fuste > galhos > casca do fuste > folhas. 0 fuste (madeira + casca) acumulou 91,5\% da biomassa total no tratamento SEPi e 91,2\% no tratamento CEPi. Já a copa (folhas + galhos) apresentou um acúmulo de 8,5 e 9,0\% nos tratamentos SEPi e CEPi, respectivamente. Os resultados indicam que 0 híbrido de eucalipto manteve produção satisfatória de biomassa, apesar da menor disponibilidade de água.

Palavras-chave: tolerância à seca; exclusão da precipitação interna; crescimento arbóreo; produtividade arbórea; déficit hídrico 


\section{Introduction}

Eucalypts stands have multiple functions in the landscapes of different Brazilian ecosystems (Gonçalves et al., 2013). In the country, areas planted with the genus Eucalyptus occupies approximately 9.8 million hectares (IBGE, 2017).

Eucalypt species have adapted to different edaphoclimatic conditions, associated with easy seed propagation and cloning, as well as high productivity, stimulated by the establishment of stands by several companies (Gonçalves et al., 2013). However, despite eucalypts plantations are among the most productive, the rates of growth depend heavily on genetics of species, silviculture, and climate (Binkley et al., 2017).

The tree biomass production varies according to the availability of resources, processes of photosynthesis, respiration, compartmentalization of carbon, belowground flux, leaf production, among others (Ryan et al., 2010). The quantification of forest biomass allows the determination of the production potential and the indication of certain species/ clones for specific purposes (Kuyah et al., 2013).

Most eucalypt plantations are located in areas vulnerable to water deficits, with low precipitation throughout the year, which can compromise plant growth. In many places, tree biomass reduction may be associated with soil water deficits, due to low rainfall, which leads to an increased tree mortality rates (Chagas et al., 2012). Several authors observed biomass reduction in areas with lower water availability (Almeida et al., 2004; Silva et al., 2004; Stape et al., 2010; Ryan et al., 2010; Binkley et al., 2017; Binkley et al., 2020).

Thus, it is important to understand how trees respond to water deficits and what role this plays in its development (Chaves et al., 2009). This subject is particularly relevant in forestry science, as different genotypes may vary in their response to the water deficits. The present work aims to estimate aboveground biomass production in a Eucalyptus urophylla $\times$ Eucalyptus sp. hybrid under two water regimes.

\section{Materials and Methods}

\section{Location of the experimental area}

The present work is part of the cooperative program TECHS (Tolerance of Eucalyptus Clones to Hydric and thermal Stresses) and was carried out in a stand of 76-month-old, hybrid Eucalyptus urophylla $\times$ Eucalyptus sp. trees. The experimental area is located at Monte Alegre Farm (Klabin $\mathrm{SA}$ ), in the municipality of Telêmaco Borba, Paraná (PR), Brazil $\left(24^{\circ} 13^{\prime} 41.0^{\prime \prime} \mathrm{S}, 50^{\circ} 31^{\prime} 40,0^{\prime \prime} \mathrm{W}\right)$.

\section{Characterization of the experimental area}

According to Köppen's climatic classification, the prevailing climate is humid subtropical ( $\mathrm{Cfb}$ ), with an average annual temperature of $18.8^{\circ} \mathrm{C}$ and an average annual rainfall of 1,646 $\mathrm{mm}$ (Alvares et al., 2013). In the period of growth of trees of this study, the average rainfall was 1,504 mm (Figure 1).

The soil in the experimental area is a typical Red Oxisol, with a clay texture. Table 1 presents the clay percentage and chemical characteristics of the soil from 0 to $60 \mathrm{~cm}$ of depth.

\section{Site preparation}

The trees were planted in February 2012, with $3 \mathrm{~m} \times 3 \mathrm{~m}$ spacing, for an initial density of 1,111 trees per hectare. At planting, we applied liming at $2 \mathrm{Mg} \mathrm{ha}^{-1}$ with limestone and subsoiling at $50 \mathrm{~cm}$ depth. Fertilization was provided as $200 \mathrm{~kg}$ $\mathrm{ha}^{-1}$ of reactive natural phosphate and $280 \mathrm{~kg} \mathrm{ha}^{-1}$ of $\mathrm{N}-\mathrm{P}_{2} \mathrm{O}_{5}-\mathrm{K}_{2} \mathrm{O}$ (04:26:06). Two post-planting fertilizations took place at three and nine months, with $200 \mathrm{~kg} \mathrm{ha}^{-1}$ of $\mathrm{N}-\mathrm{P}_{2} \mathrm{O}_{5}-\mathrm{K}_{2} \mathrm{O}$ (16:04:20) and $350 \mathrm{~kg} \mathrm{ha}^{-1}$ of $\mathrm{N}-\mathrm{P}_{2} \mathrm{O}_{5}-\mathrm{K}_{2} \mathrm{O}$ (16:04:20), respectively. All trees received the same fertilization. Weeds and leaf-cutting ants were controlled with herbicides and insecticides.

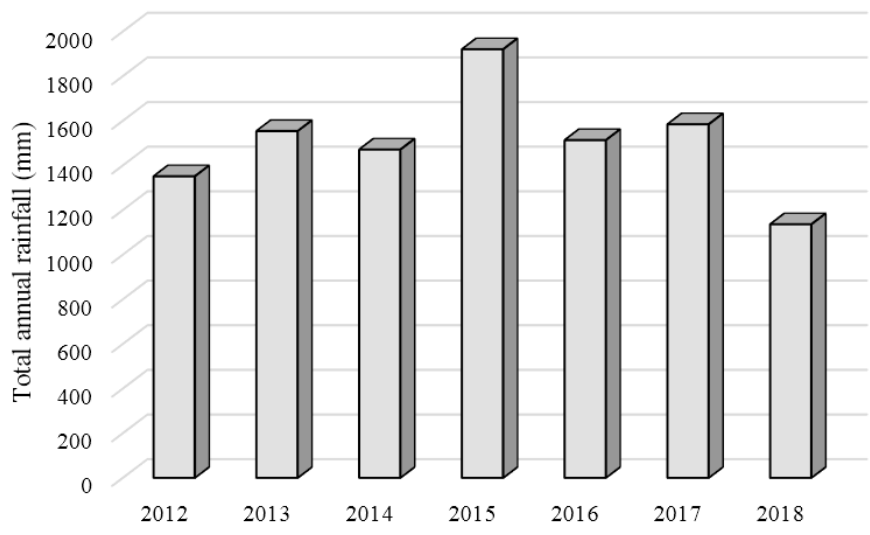

Figure 1. Annual rainfall of the municipality of Telêmaco Borba, PR, Brazil, during the growth of trees of this study (2012 to 2018). Source: Agência Nacional de Águas (2018); Klabin S.A. (2018).

Table 1. Clay percentage and soil chemical attributes in the stand of hybrid Eucalyptus urophylla $\times$ Eucalyptus sp. trees, in Telêmaco Borba, PR, Brazil.

\begin{tabular}{|c|c|c|c|c|c|c|c|c|c|c|c|c|c|c|c|c|}
\hline \multirow{2}{*}{$\begin{array}{l}\text { Depth } \\
(\mathrm{cm})\end{array}$} & Clay & O.M. & V & $\bar{m}$ & \multirow{2}{*}{$\begin{array}{c}\mathrm{pH} \\
\left(\mathrm{H}_{2} \mathrm{O}\right)\end{array}$} & $\bar{t}$ & $T$ & $\mathrm{Al}$ & $\mathrm{Ca}$ & $\mathrm{Mg}$ & $\mathbf{P}$ & $\bar{K}$ & $s$ & B & $\mathrm{Cu}$ & $\mathrm{Zn}$ \\
\hline & \multicolumn{4}{|c|}{ (\%) } & & \multicolumn{5}{|c|}{ (cmolc dm-3) } & \multicolumn{6}{|c|}{$\left(\mathrm{mg} \mathrm{dm}^{-3}\right)$} \\
\hline $0-10$ & 43.0 & 4.8 & 5.0 & 76.3 & 4.1 & 3.8 & 18.2 & 2.9 & 0.5 & 0.3 & 2.1 & 44.0 & 11.6 & 0.2 & 3.3 & 1.6 \\
\hline $10-20$ & 47.0 & 3.6 & 2.8 & 81.8 & 4.1 & 3.3 & 20.0 & 2.7 & 0.3 & 0.2 & 1.5 & 32.0 & 7.9 & 0.2 & 3.7 & 1.2 \\
\hline $20-30$ & 47.0 & 2.8 & 2.6 & 82.1 & 4.2 & 2.8 & 17.8 & 2.3 & 0.3 & 0.1 & 1.1 & 24.0 & 12.5 & 0.1 & 3.7 & 0.8 \\
\hline $30-40$ & 50.0 & 3.0 & 2.4 & 83.3 & 4.3 & 2.4 & 17.7 & 2.0 & 0.3 & 0.1 & 1.0 & 20.0 & 13.0 & 0.2 & 3.2 & 0.8 \\
\hline $40-50$ & 59.0 & 2.6 & 2.1 & 85.3 & 4.3 & 2.0 & 15.7 & 1.7 & 0.2 & 0.1 & 1.5 & 20.0 & 3.2 & 0.2 & 3.9 & 1.4 \\
\hline $50-60$ & 62.0 & 2.6 & 3.7 & 76.2 & 4.3 & 2.1 & 12.8 & 1.6 & 0.3 & 0.1 & 1.5 & 16.0 & 6.9 & 0.2 & 3.0 & 1.2 \\
\hline
\end{tabular}

O.M.: organic matter, digestion by wet combustion $\left(\mathrm{K}_{2} \mathrm{Cr}_{2} \mathrm{O}_{7}+\mathrm{H}_{2} \mathrm{SO}_{4}\right)$; $\mathrm{V}$ : base saturation; $\mathrm{m}$ : aluminum saturation; $\mathrm{pH}$ in $\mathrm{H}_{2} \mathrm{O}$ (1:1); $\mathrm{t}$ : effective cation exchange capacity; $\mathrm{T}$ : $\mathrm{pH} 7$ cation exchange capacity; $\mathrm{Al}, \mathrm{Ca}$ and $\mathrm{Mg}$ exchangeable, solution extraction $\mathrm{KCl}\left(1 \mathrm{~mol} \mathrm{~L}^{-1}\right) ; \mathrm{P}$ available and $\mathrm{K}$ exchangeable, extracted with $\mathrm{Mehlich}$; $\mathrm{S}$, by solution of $\left.\mathrm{Ca}\left(\mathrm{H}_{2} \mathrm{PO}\right)_{4}\right)_{2}$ the 500 mg of $P L^{-1}$. 


\section{Experiment design and installation}

The experiment treatments consisted of two water regimes: one with throughfall (WET), receiving $100 \%$ of the throughfall, and the other with the partial exclusion of throughfall (PET), receiving only $70 \%$. Throughfall reduction was achieved by installing plastic gutters (when the trees were 12 months old) to intercept $30 \%$ of the rainfall (Figure 2). The experimental design was completely randomized and each treatment had $720 \mathrm{~m}^{2}$.

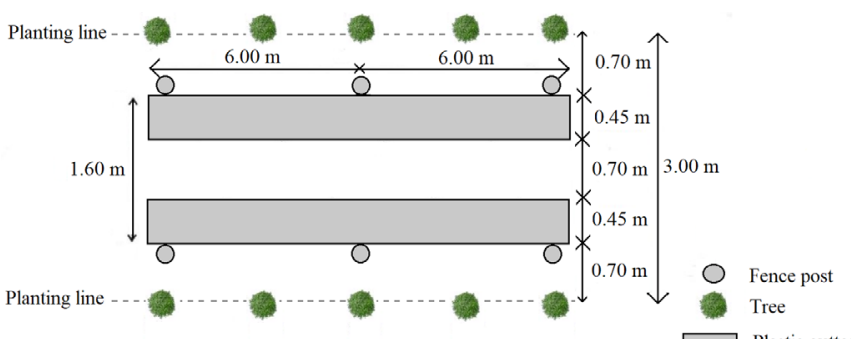

Figure 2. Illustrative of the arrangement of plastic gutters for partial exclusion of throughfall in the experimental area in Telêmaco Borba, PR, Brazil.

\section{Aboveground biomass evaluation}

In April 2018 a forest inventory was carried out in the study area to characterize the dendrometric variables. In both treatments, the trees were measured for diameter at breast height $(\mathrm{DBH})$, measured at $1.30 \mathrm{~m}$ aboveground level, and heights.

The tree diameters were grouped into three interval classes, to cover all dimensions (Table 2). In each class center, three trees were selected: a tree with a diameter in the center of the class, a tree with a diameter in the center of the class plus one standard deviation, and a tree with a diameter in the center of the class minus one standard deviation. Thus, nine trees per treatment were selected. Table 3 presents the dendrometric variables obtained from the hybrid Eucalyptus urophylla $x$ E. sp. stand.

The selected trees were sectioned and fractionated into the following components: leaves, branches, stembark, and stemwood. For the wood and stembark sampling, the trunk was divided into three equal sections, and sampling occurred at three points within the median of each section.

All biomass samples were weighed in the field with a precision scale $( \pm 0,0001 \mathrm{~g})$ and packed in paper bags.

Table 2. Diametric classes in the hybrid of Eucalyptus urophylla $\mathrm{x}$ Eucalyptus sp. stand in Telêmaco Borba, PR, Brazil.

\begin{tabular}{cccc|cc}
\hline Treatment & Class & $\begin{array}{c}\text { IC } \\
(\mathbf{c m})\end{array}$ & CC & Tree ha-1 \\
\hline \multirow{2}{*}{ WET } & 1 & 12.73 & --15.58 & 14.15 & 97 \\
& 2 & 15.59 & --18.43 & 17.01 & 361 \\
& 3 & 18.44 & --21.28 & 19.86 & 597 \\
\multirow{2}{*}{ PET } & 1 & 13.30 & --16.03 & 14.65 & 167 \\
& 2 & 16.04 & --18.80 & 17.42 & 708 \\
& 3 & 18.81 & --21.57 & 20.19 & 222 \\
\hline
\end{tabular}

IC: interval class (cm); CC: class center; WET: without partial exclusion of throughfall; PET: partial exclusion of throughfall.
Table 3. Dendrometric variables of the hybrid Eucalyptus urophylla $\times$ Eucalyptus sp. stand in Telêmaco Borba, PR, Brazil.

\begin{tabular}{cccccc}
\hline Treatment & $\begin{array}{c}\text { DBH } \\
(\mathbf{c m})\end{array}$ & $\begin{array}{c}\text { Height } \\
(\mathbf{m})\end{array}$ & Tree ha-1 & $\begin{array}{c}\text { Basal area } \\
\left(\mathbf{m}^{\mathbf{2}} \mathbf{h a}^{-1}\right)\end{array}$ & $\begin{array}{c}\text { Volume } \\
\left(\mathbf{m}^{\mathbf{3}} \mathbf{h a}^{-1}\right)\end{array}$ \\
\hline WET & $17.34 \mathrm{a}$ & $28.35 \mathrm{a}$ & 1055 & $25.52 \mathrm{a}$ & $365.08 \mathrm{a}$ \\
PET & $16.78 \mathrm{~b}^{*}$ & $28.57 \mathrm{a}$ & 1097 & $24.13 \mathrm{~b}$ & $346.18 \mathrm{a}$ \\
\hline
\end{tabular}

"Same letter in the same column indicates that the components do not differ significantly (Student's $t$-test at the $5 \%$ level of error). DBH: diameter at breast height; WET: without partial exclusion of throughfall; PET: partial exclusion of throughfall.

Afterward, they were sent to the laboratory and dried in a oven with air circulation at $70{ }^{\circ} \mathrm{C}$, until weight stabilization. All of the samples were reweighed on a precision digital scale $( \pm 0.01 \mathrm{~g})$ to determine the moisture content.

The basic density of wood ( $\mathrm{Bdw}$ ) and bark (Bdb) was determined by the hydrostatic balance method. The disks with bark were saturated with water and subsequently cut into two wedges (free of nodes) on opposite sides and with an angle of approximately $45^{\circ}$ each. For each wedge and bark sample, the weight immersed in water (Ww), the saturated weight (Sw), and the dry weight (Dw) were obtained. The Equations 1 and 2 were used to calculate the basic density of wood and bark (Ferez, 2010).

$$
\begin{gathered}
B d w=\frac{\rho \cdot D w}{S w-W w} \\
B d b=\frac{\rho \cdot D w}{S w-W w+e}
\end{gathered}
$$

where: Bdw: basic density of wood $\left(\mathrm{g} \mathrm{cm}^{-3}\right)$; Bdb: basic density of bark $\left(\mathrm{g} \mathrm{cm}^{-3}\right)$; $\rho$ : water density $\left(\mathrm{g} \mathrm{cm}^{-3}\right)$; Dw: dry weight $(\mathrm{g})$; Sw: saturated weight (g); Ww: weight immersed in water (g); e: thrust weight (g).

Biomass was estimated by means of regression equations, calculated using the data from the nine trees sampled in each treatment (WET vs. PET). Wood biomass was calculated using the Equation 3.

$$
\text { Wood Biomass }=\mathrm{Bdw} \times \mathrm{VW}
$$

where: wood biomass ( $\left.\mathrm{kg} \mathrm{ha}^{-1}\right)$; Bdw: basic density of wood $\left(\mathrm{kg} \mathrm{m}^{-3}\right)$; Vw: volume of wood $\left(\mathrm{m}^{3}\right.$ tree $\left.^{-1}\right)$.

To obtain the biomass of the bark, the Equation 4 was used.

$$
\text { Bark Biomass }=\mathrm{Bdb} \times \mathrm{Vb}
$$

where: bark biomass ( $\left.\mathrm{kg} \mathrm{ha}^{-1}\right)$; Bdb: basic density of bark $\left(\mathrm{kg} \mathrm{m}^{-3}\right)$; $\mathrm{Vb}$ : volume of bark $\left(\mathrm{m}^{3}\right.$ tree $\left.^{-1}\right)$.

The biomass estimation was performed by the Equation 5 proposed by Husch et al. (1982).

$$
\ln (y)=\beta_{0}+\beta_{1} \times \ln (\mathrm{DBH})
$$

where: In (y) represents the natural logarithm of dry biomass $\left(\mathrm{kg} \mathrm{tree}^{-1}\right), \ln (\mathrm{DBH})$ the natural logarithm of the $\mathrm{DBH}(\mathrm{cm})$, and $\beta_{0}$ and $\beta_{1}$ the regression coefficients. 
Table 4. Statistical adjustment parameters of the regression model used to estimate the biomass of a hybrid of Eucalyptus urophylla $\times$ Eucalyptus sp. stand at 76-month-old, in Telêmaco Borba, PR, Brazil.

\begin{tabular}{ccccccc}
\hline Treatment & Component & $\boldsymbol{\beta 0}$ & $\boldsymbol{\beta 1}$ & $\mathbf{R}^{\mathbf{2}}$ & Sxy & P>F \\
\hline \multirow{4}{*}{ WET } & Stemwood & -3.542995 & 2.998741 & 0.96 & 18.90 & $<0.001$ \\
& Stembark & -6.441550 & 2.958277 & 0.95 & 0.91 & $<0.001$ \\
& Branches & -6.323210 & 3.031591 & 0.75 & 1.32 & 0.002 \\
& Leaves & -12.729654 & 4.980533 & 0.91 & 1.27 & $<0.001$ \\
& Stemwood & -1.986885 & 2.466944 & 0.97 & 11.30 & $<0.001$ \\
& Stembark & -5.544016 & 2.656450 & 0.89 & 0.95 & 0.001 \\
& Branches & -7.702530 & 3.541063 & 0.77 & 1.34 & 0.001 \\
& Leaves & -7.374071 & 3.137208 & 0.85 & 1.05 & 0.003 \\
\hline
\end{tabular}

$\beta_{0}$ and $\beta_{1}$ : regression coefficients; $R^{2}$ : determination coefficient; Sxy: standard error; WET: without partial exclusion of throughfall; PET: partial exclusion of throughfall.

The coefficients and statistics of the regression model used to estimate biomass components are shown in Table 4.

\section{Statistical analysis}

The biomass data was checked with the Shapiro-Wilk normality test and Bartlett's variance homogeneity test. Next, an analysis of variance was performed. Differences between the treatment means were tested with a Student's $t$-test $(\mathrm{p}$ $<0.05$ ). Modeling to estimate the aboveground biomass was performed in Microsoft Office Excel.

\section{Results and Discussion}

Total biomass of Eucalyptus urophylla $\times$ Eucalyptus $\mathrm{sp}$. hybrid was $6 \%$ higher in the WET treatment $(221.00 \mathrm{Mg}$ ha $\left.{ }^{1}\right)$ than in the PET treatment $\left(208.26 \mathrm{Mg} \mathrm{ha}^{-1}\right)$ (Table 5). The search for genotypes tolerant to water deficits represents a challenge for forest companies; these results may be relevant to the success of forest stands, selecting more productive clones in situations of lower water availability.

Know the growth of different clones in climatic variation is important for improvements in site management (Scolforo et al., 2017). According to Binkley et al. (2017), climate a lot influences the growth of planted forests of Eucalyptus and a dry period may can change wood production of one-third over a six-to-seven-year rotation (Almeida et al., 2010). The same way as increases in the value of agricultural crops could lead to implantation of Eucalyptus stands in places with less water availability, which it would require more efficient genotypes and new management practices (Binkley et al., 2017).

Oliveira (2017) evaluated the biomass of 47-monthold $E$. urophylla $\times$ Eucalyptus $s p$. hybrids in three different edaphoclimatic regions of Minas Gerais (Belo Oriente, Coração de Jesus, and Guanhães municipalities) and they reported values of $108.60 \mathrm{Mg} \mathrm{ha}^{-1}, 60.90 \mathrm{Mg} \mathrm{ha}^{-1}$, and 125.30 $\mathrm{Mg} \mathrm{ha}{ }^{-1}$, respectively. Santana et al. (2008) incorporated climatic characteristics into their models of eucalypts biomass production for different regions in Brazil and they figure out that age, temperature, and the availability of water were important factors. The authors also compared biomass production between regions of high and low productivity and reported lower productivity in regions with lower water availability. In this context, the genetics, edaphoclimatic factors, and management systems are directly related to the biomass production capacity of the eucalypts species / clones (Stape et al., 2010; Gonçalves et al., 2013; Binkley et al., 2020).

The wood production in the WET treatment was significantly higher than in the PET treatment $\left(192.73 \mathrm{Mg} \mathrm{ha}^{-1}\right.$ vs. 180.88 $\mathrm{Mg} \mathrm{ha}^{-1}$ ) (Table 5). Several studies have demonstrated strong relationship between water supply and wood production of genus Eucalyptus. Ryan et al. (2010) (Aracruz-ES, International Paper-SP, Suzano-BA, and Veracel-BA) reported that an increase in water supply triggered higher wood production. Silva et al. (2004) reported a reduction of approximately $46 \%$ in the mean total biomass of young Eucalyptus sp. plants cultivated with $50 \%$ less water. Binkley et al. (2017) studied clonal Eucalyptus plantations across Brazil and Uruguay and related that stemwood production increase an average of 1.5 $\mathrm{Mg} \mathrm{ha}^{-1} \mathrm{yr}^{-1}$ for each $100 \mathrm{~mm} \mathrm{yr}^{-1}$ increase in precipitation.

The WET treatment also presented higher leaves production than the PET treatment (9.43 $\left.\mathrm{Mg} \mathrm{ha}^{-1} \mathrm{vs} .8 .41 \mathrm{Mg} \mathrm{ha}^{-1}\right)$. According to Stape et al. (2004), the productivity of stands of Eucalyptus is likely constrained by water supply, what could influence in biomass allocation of roots, stems, and leaves.

The distribution of aboveground biomass in both treatments was as follows: stemwood $>$ branches $>$ stembark $>$ leaves. The stem (wood + bark) accounted for $91.5 \%$ of the total biomass in the WET treatment and $91.2 \%$ in the PET treatment. A much

Table 5. Biomass of the different components of a hybrid of Eucalyptus urophylla $\times$ Eucalyptus sp. tree stand at 76-month-old, under two water regimes, in Telêmaco Borba, PR, Brazil.

\begin{tabular}{|c|c|c|c|c|c|}
\hline \multirow{2}{*}{ Treatment } & \multicolumn{5}{|c|}{ Component (Mg ha-1) } \\
\hline & Stemwood & Stembark & Branches & Leaves & Total \\
\hline \multirow{2}{*}{ WET } & $192.73 a^{*}$ & $9.43 a$ & $13.16 a$ & $6.66 a$ & $221.98 a$ \\
\hline & (87) & (4) & (6) & (3) & $(100)$ \\
\hline \multirow{2}{*}{ PET } & $180.88 b^{*}$ & $8.91 b$ & $13.25 a$ & $5.73 b$ & $208.77 a$ \\
\hline & (87) & (4) & (6) & (3) & $(100)$ \\
\hline
\end{tabular}

"Same letter in the same column indicates that the components do not differ significantly (Student's $t$-test at the $5 \%$ level of error); Values in parentheses represent the relative biomass. WET: without partial exclusion of throughfall; PET: partial exclusion of throughfall. 
proportion of the biomass production is allocated to stemwood, which were found in mid-aged stands (4-7-year-old), compared to young and old aged shoots. Generally, stemwood contributes to more than $50 \%$ of the aboveground biomass (Zewdie et al., 2009). According to Schumacher et al. (2011), before the closure of the canopy, there is a period of intense growth in which most of the photoassimilates synthesized by the plant are channeled into the canopy and root systems. After the crowning of the tree canopy, the accumulation of nutrients in the trunks occurs with more intensity, as the formation of the canopy reaches a phase of relative stability, due to auto-shading.

\section{Conclusion}

The hybrid Eucalyptus urophylla $\times$ Eucalyptus sp. maintained a satisfactory production of biomass, despite the lower availability of water.

Naturally, the tree component with the highest aboveground biomass was stemwood, followed by branches, stembark and leaves, in both treatments.

\section{Acknowledgements}

The authors thank the Company Klabin S.A. and the Forestry Science and Research Institute (IPEF).

\section{Literature Cited}

Agência Nacional de Águas. HIDROWEB v3.1.1. http://www.snirh. gov.br/hidroweb. 10 Jan. 2019.

Almeida, A.C.; Landsberg, J.J.; Sands, P.J.; Ambrogia, M.S.; Fonseca, S.; Barddal, S.M.; Bertolucci, F.L. Needs and opportunities for using a process-based productivity model as a practical tool in Eucalyptus plantations. Forest Ecology and Management, v.193, n.1-2, p.167-177, 2004. https://doi.org/10.1016/j.foreco.2004.01.044.

Almeida, A.C.; Siggins, A.; Batista, T.R.; Beadle, C.B.; Fonseca, S.; Loos, R. Mapping the effect of spatial and temporal variation in climate and soils on Eucalyptus plantation production with 3-PG, a process-based growth model. Forest Ecology and Management, v.259, n.9, p.1730-1740, 2010. https://doi.org/10.1016/j. foreco.2009.10.008.

Alvares, C.A.; Stape, J.L.; Sentelhas, P.C.; Gonçalves, J.L.M.; Sparovek, G. Köppen's climate classification map for Brazil. Meteorologische Zeitschrift, v.22, n.6, p.1-18, 2013. https://doi.org/10.1127/09412948/2013/0507.

Binkley, D.; Campoe, O.C.; Alvares, C.; Carneiro, R.L.; Cegatta, I.; Stape, J.L. The interactions of climate, spacing and genetics on clonal Eucalyptus plantations across Brazil and Uruguay. Forest Ecology and Management, v.405, p.271-283, 2017. https://doi. org/10.1016/j.foreco.2017.09.050.

Binkley, D.; Campoe, O.C.; Alvaresc, C.A.; Carneiro, R.L.; Stape, J.L. Variation in whole-rotation yield among Eucalyptus genotypes in response to water and heat stresses: The TECHS project. Forest Ecology and Management, v.462, e117953, 2020. https://doi. org/10.1016/j.foreco.2020.117953.
Chagas, G.F.B.; Silva, V.P.R.; Costa, A.C.L.; Dantas, V.A. Impactos da redução da pluviometria na biomassa aérea da Floresta Amazônica. Revista Brasileira de Engenharia Agrícola e Ambiental, v.16, n.1, p.72-79, 2012. https://doi.org/10.1590/ S1415-43662012000100010.

Chaves, M.M.; Flexas, J.; Pinheiro, C. Photosynthesis under drought and salt stress: regulation mechanisms from whole plant to cell. Annals of Botany, v.103, n.4, p.551-560, 2009. https://doi. org/10.1093/aob/mcn125.

Ferez, A.P.C. Efeito de práticas silviculturais sobre taxas iniciais de sequestro de carbono em plantios de restauração da Mata Atlântica. Piracicaba: Universidade de São Paulo, Escola Superior de Agricultura "Luiz de Queiroz", 2010. 104p. Dissertação Mestrado. https://doi.org/10.11606/D.11.2011.tde-08022011140851.

Gonçalves, J.L.M.; Alvares, C.A.; Higa, A.R.; Silva, L.D.; Alfenas, A.C.; Stahl, J.; Ferraz, S.B.; Lima, W.P.; Brancalion, P.H.S.; Hubner, A.; Bouillet, J.P.D.; Laclau, J.P.; Nouvellon, Y.; Epron, D. Integrating genetic and silvicultural strategies to minimize abiotic and biotic constraints in Brazilian eucalypt plantations. Forest Ecology and Management, v.301, p.6-27, 2013. https://doi.org/10.1016/j. foreco.2012.12.030.

Husch, B.; Miller, C.I.; Beers, T.W. Forest mensuration. New York: John Wiley \& Sons, 1982. 402 p.

Instituto Brasileiro de Geografia e Estatística - IBGE. Produção da extração vegetal e da silvicultura. Rio de Janeiro: IBGE, 2017. v.32, p.1-8. https://agenciadenoticias.ibge.gov.br/media/com_ mediaibge/arquivos/15f538e9095614fc3204f828b22fa714.pdf. 10 Nov. 2019.

Klabin S.A. Dados climáticos [mensagem pessoal]. Mensagem recebida por MAFigura@Klabin.com.br. 17 Jul. 2018.

Kuyah S.; Dietz J.; Muthuri C.; Noordwijk M.; Neufeldt H. Allometry and partitioning of above- and bellow-ground biomass in farmed eucalyptus species dominant in Western Kenyan agricultural landscapes. Biomass and Bioenergy, v.55, n.1, p.276-284, 2013. https://doi.org/10.1016/j.biombioe.2013.02.011.

Oliveira, J.R. Crescimento, produção e eficiência nutricional de genótipos de eucalipto em diferentes condições edafoclimáticas de Minas Gerais. Viçosa: Universidade Federal de Viçosa, 2017. 150p. Tese Doutorado. http://www.locus.ufv.br/ handle/123456789/11581. 05 Nov. 2019.

Ryan, M.G.; Stape, J.L.; Binkley, D.; Fonseca, S.; Loos, R.A.; Takahashi, E.N.; Silva, C.R.; Silva, S.R.; Hakamada, R.E.; Ferreira, J.M.; Lima, A.M.N.; Gava, J.L.; Leite, F.P.; Andrade, H.B.; Alves, J.M.; Silva, G.G.C. Factors controlling Eucalyptus productivity: How water availability and stand structure alter production and carbon allocation. Forest Ecology and Management, v.259, n.9, p.16951703, 2010. https://doi.org/10.1016/j.foreco.2010.01.013.

Santana, R.C.; Barros, N.F.; Novais, R.F.; Leite, H.G.; Comerford, N.B. Alocação de nutrientes em plantios de eucalipto no Brasil. Revista Brasileira de Ciência do Solo, v.26 n.4, p.447-457, 2008. https:// doi.org/10.1590/S0100-06832008000700016.

Schumacher, M.V.; Witschoreck, R.; Calil, F.N. Biomassa em povoamentos de Eucalyptus spp. de pequenas propriedades rurais em Vera Cruz, RS. Ciência Florestal, v.21, n.1, p.17-22, 2011. https://doi.org/10.5902/198050982743. 
Scolforo, H.F.; Scolforo, J.R.S.; Stape, J.L.; McTague, J.P.; Burkhart, H.; McCarter, J.; Castro Neto, F.; Loos, R.A.; Sartorio, R.C. Incorporating rainfall data to better plan eucalyptus clones deployment in eastern Brazil. Forest Ecology and Management, v.391, p.145153, 2017. https://doi.org/10.1016/j.foreco.2017.02.025.

Silva, F.C.; Shvaleva, A.; Maroco, J.P.; Almeida, M.H.; Chaves, M.M.; Pereira, J.S. Responses to water stress in two Eucalyptus globulus clones differing in drought tolerance. Tree Physiology, v.24, n.10, p.1165-1172, 2004. https://doi.org/10.1093/treephys/24.10.1165.

Stape, J.L.; Binkley, D.; Ryan, M.G. Eucalyptus production and the supply, use and efficiency of use of water, light and nitrogen across a geographic gradient in Brazil. Forest Ecology and Management, v.193, n.1-2, p.17-31, 2004. https://doi. org/10.1016/j.foreco.2004.01.020.
Stape, J.L.; Binkley, D.; Ryan, M.G.; Fonseca, S.; Loos, R.; Takahashi, E.N.; Silva, C.R.; Silva, S.; Hakamada, R.; Ferreira, J.M., Lima, A.M.; Gava, J.L.; Leite, F.P.; Silva, G.; Andrade, H.; Alves, J.M. The Brazil eucalyptus potential productivity project: influence of water, nutrients and stand uniformity on wood production. Forest Ecology and Management, v.259, n.9, p.1686-1694, 2010. https://doi.org/10.1016/j. foreco.2010.01.012.

Zewdie, M.; Olsson, M.; Verwijst, T. Above-ground biomass production and allometric relations of Eucalyptus globulus Labill. coppice plantations along a chronosequence in the central highlands of Ethiopia. Biomass and bioenergy, v.33, n.3, p.421-428, 2009. https://doi.org/10.1016/j. biombioe.2008.08.007. 